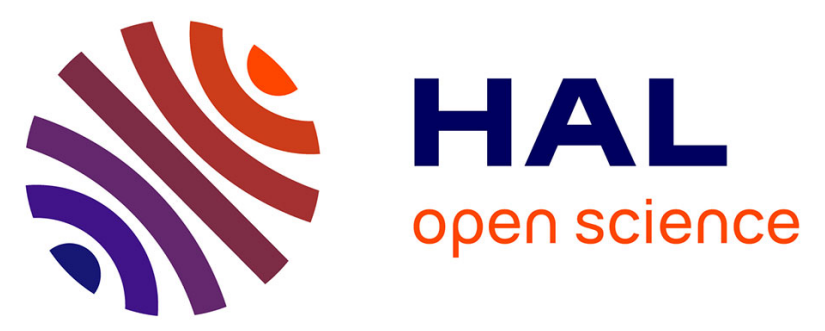

\title{
Solving the Challenging Synthesis of Highly Cytotoxic Silver Complexes Bearing Sterically Hindered NHC Ligands with Mechanochemistry
}

Audrey Beillard, François Quintin, Jeremie Gatignol, Pascal Retailleau, Jean-Luc Renaud, Sylvain Gaillard, Thomas-Xavier Métro, Frédéric Lamaty, Xavier Bantreil

\section{To cite this version:}

Audrey Beillard, François Quintin, Jeremie Gatignol, Pascal Retailleau, Jean-Luc Renaud, et al.. Solving the Challenging Synthesis of Highly Cytotoxic Silver Complexes Bearing Sterically Hindered NHC Ligands with Mechanochemistry. 2020. hal-03000794

\section{HAL Id: hal-03000794 https://hal.science/hal-03000794}

Preprint submitted on 12 Nov 2020

HAL is a multi-disciplinary open access archive for the deposit and dissemination of scientific research documents, whether they are published or not. The documents may come from teaching and research institutions in France or abroad, or from public or private research centers.
L'archive ouverte pluridisciplinaire HAL, est destinée au dépôt et à la diffusion de documents scientifiques de niveau recherche, publiés ou non, émanant des établissements d'enseignement et de recherche français ou étrangers, des laboratoires publics ou privés. 


\title{
Solving the Challenging Synthesis of Highly Cytotoxic Silver Complexes bearing Sterically Hindered NHC Ligands with Mechanochemistry
}

\author{
Audrey Beillard, ${ }^{a}$ François Quintin, ${ }^{a}$ Jérémie Gatignol,b Pascal Retailleau,c Jean-Luc Renaud,

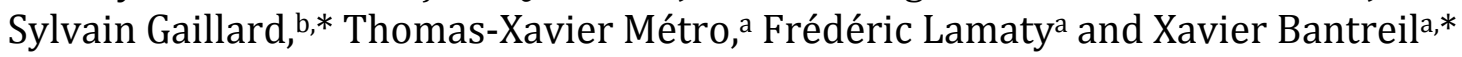 \\ a IBMM, Univ Montpellier, CNRS, ENSCM, Montpellier, France. E-Mail: xavier.bantreil@umontpellier.fr \\ b Normandie University, LCMT, ENSICAEN, UNICAEN, CNRS, 14000, Caen, France. E-Mail: \\ sylvain.gaillard@ensicaen.fr \\ c Institut de Chimie des Substances Naturelles, CNRS UPR 2301, Université Paris-Saclay, 1 Avenue de la Terrasse, \\ 91198 Gif-sur-Yvette, France
}

\begin{abstract}
The use of ball-mills enabled the straightforward synthesis of a variety of silver(I) complexes featuring challenging NHC ligands. Sterically hindered including electron-poor or with very low solubility imidazolium salts were grinded with silver(I) oxide to furnish heteroleptic or homoleptic complexes in high yield and short reaction times. The synthesis of heteroleptic bis-NHC silver(I) complexes was also performed for the first time in a ball-mill. The efficiency and rapidity of the mechanochemical approach enabled the generation of a library of unprecedented NHC silver complexes, which cytotoxicity on HCT116 colorectal cancer cell line was evaluated providing a rare example of medicinal mechanochemistry. The cationic silver complexes were found more potent than the neutral analogues, with $\mathrm{IC}_{50}$ values down to $21 \mathrm{nM}, 256$ times more potent than cisplatin.
\end{abstract}

$N$-heterocyclic carbenes (NHC) are widely used for the stabilization of transition metals, especially compared to phosphines in catalytic systems. ${ }^{1}$ Additionally, NHCbased complexes have found interest due to their biological properties, for example for their antibacterial, antifungal or anticancer properties. ${ }^{2}$ Besides, many groups have shown that NHC-gold(I) and NHC-gold(III) complexes could be valid alternatives to cisplatin due to their different mode of action. ${ }^{3}$ Silver(I) complexes have also been studied because they might behave similarly to gold complexes.2a-e, 4 However, NHC-silver(I) complexes have mostly been studied for their antibacterial and antimicrobial activity, ${ }^{5}$ and only some of them were found to be active as anticancer agents. ${ }^{6}$ However, most of these complexes were either neutral [AgCl(NHC)] complexes or cationic homoleptic [Ag(NHC) 2 complexes featuring $N, N$-dialkyl ligands. Cationic homoleptic $\left[\mathrm{Ag}(\mathrm{NHC})_{2}\right]$ complexes bearing $\mathrm{N}, \mathrm{N}$-diaryl NHC ligands have been less studied because their synthesis is known to be more challenging. Yet, we recently developed a mechanochemical ${ }^{7}$ solventfree method that enables a rapid and highly efficient access to such complexes. ${ }^{8}$ Additionally, ball-milling permits to easily synthesize neutral [ $\mathrm{AgCl}(\mathrm{NHC})]$ complexes, either with alkyl or aryl substituents. ${ }^{9}$ In this manuscript, we initially focused our attention on the mechanosynthesis of less conventional silver complexes bearing sterically hindered NHC including one with electron withdrawing groups, to assess if the mechanochemical approach could solve synthetic problems encountered in solution. ${ }^{7 \mathrm{~d}}$ Then, we evaluated the cytotoxicity of the corresponding complexes, as well as heteroleptic bis-NHC complexes, as anticancer agents on colorectal HCT116 cancer cell line. Of note, this represents one of the rare examples of mechanochemical synthesis of molecules for biological testing, a branch of medicinal mechanochemistry. ${ }^{10}$

First, the synthesis of neutral heteroleptic complexes was realized by milling highly encumbered imidazolium salts 1a-e and silver(I) oxide in slight excess in a stainless steel jar containing a $1 \mathrm{~cm}$ diameter stainless steel ball, using a vibratory MM400 ball-mill (Scheme 1). Gratifyingly, after $3 \mathrm{~h}$ at $30 \mathrm{~Hz}$, full conversion was obtained in all cases. Complexes 2a and $\mathbf{2 b}$, featuring ligands IProme (1,3-bis(4-methoxy2,6-diisopropylphenyl)imidazol-2-ylidene) and MeIProme (1,3-bis(4-methoxy-2,6-diisopropylphenyl)4,5-dimethylimidazol-2-ylidene) could be isolated in $81 \%$ and $86 \%$ yield, respectively. In solution, the use of electron poor ClIPr.HCl 1c (1,3-bis(2,6diisopropylphenyl)-4,5-dichloroimidazolium chloride) 

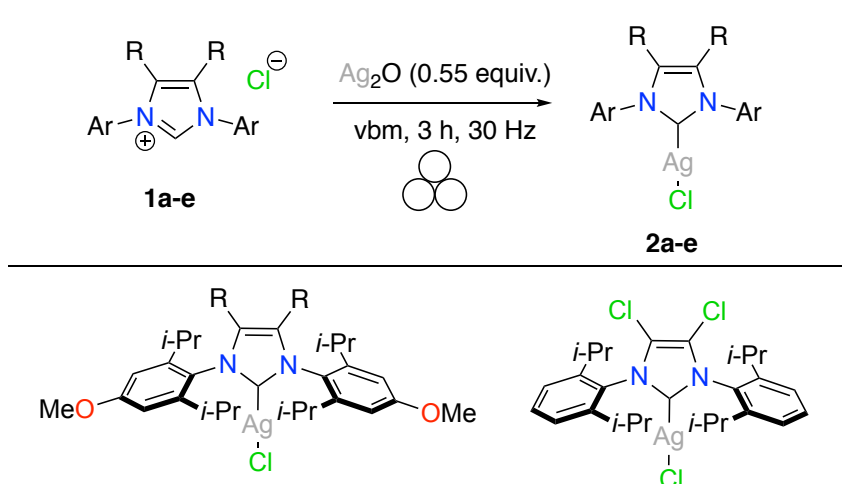

$\mathrm{R}=\mathrm{H}, \mathbf{2 a}, 81 \%$

$\mathrm{R}=\mathrm{Me}, \mathbf{2 b}, \mathbf{8 6 \%}$

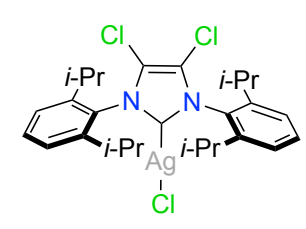

2c, $90 \%$

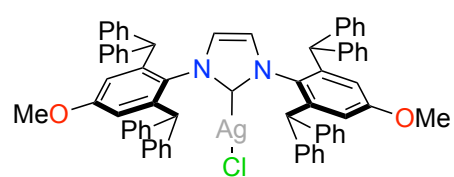

2d, $89 \%$

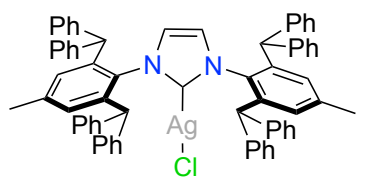

$2 e, 81 \%$
Scheme 1. Mechanosynthesis of [AgCl(NHC)] complexes bearing highly encumbered NHC ligands

revealed problematic. Indeed, even when full conversion was obtained, isolated yield of corresponding complex 2c did not exceed 31\%.11 of note, the same trend was observed in the synthesis of [CuCl(CIIPr)], with $40 \%$ being the highest reported isolated yield.12 Using the ball-mill, full conversion of 1c was also observed, but, in sharp contrast to the solution, upon treatment, complex 2c was isolated in an excellent $90 \%$ yield. Increased steric hindrance was not a limit to the method as complexes $2 \mathbf{d}$ and $\mathbf{2 e}$, featuring

IPr*OMe ([1,3-bis(4-methoxy-2,6-diphenylmethyl)phenyl]imida zol-2-ylidene) ${ }^{13}$ and

IPr* ([1,3-bis(4-methyl-2,6-diphenylmethyl)phenyl]imidaz ol-2-ylidene $)^{14}$ ligands, were isolated in $89 \%$ and $81 \%$, respectively. It is important to highlight that the solvent-free method revealed highly practical in these cases since the imidazolium salts $\mathbf{1 d}$ and $\mathbf{1 e}$ are poorly soluble in organic solvents and water.

We then turned our attention to unprecedented homoleptic $\left[\mathrm{Ag}(\mathrm{NHC})_{2}\right] \mathrm{PF}_{6}$ complexes. Imidazolium salts 1a-i were first converted into their $\mathrm{PF}_{6}$ counterpart 3a-i using either the classical method, which consists in solubilizing the chloride salt in water in the presence of $\mathrm{KPF}_{6}$ and recover the hexafluorophosphate salt that precipitates, or our previously reported solvent-free milling approach. ${ }^{8}$
Table 1. Comparison of methods for the synthesis of $\left[\mathrm{Ag}(\mathrm{Cl} \mathrm{Pr})_{2}\right] \mathrm{PF}_{6}{ }^{\mathrm{a}}$

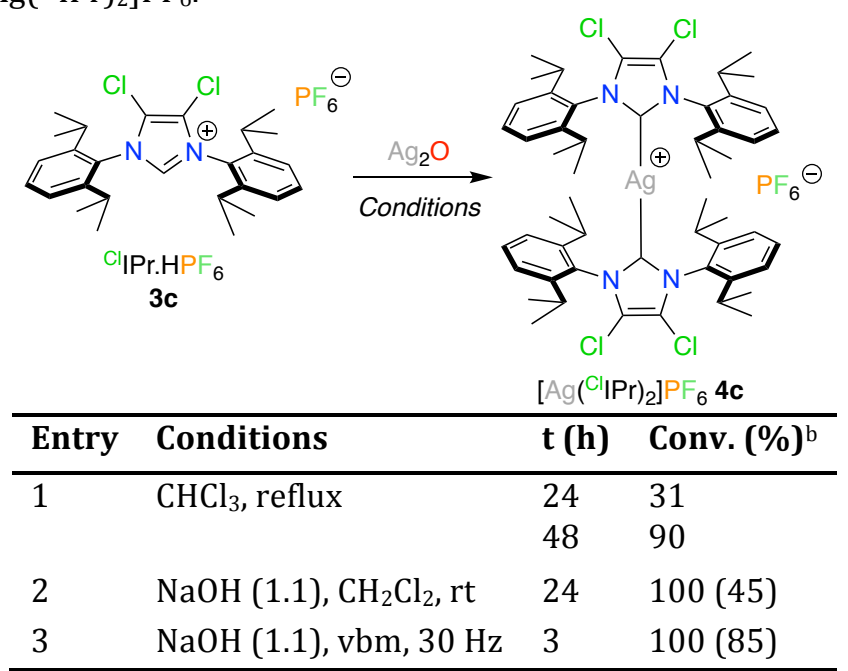

a Reaction conditions: 3c (0.15 mmol, 1 eq.), $\mathrm{Ag}_{2} \mathrm{O}$ (0.075 mmol, 0.5 eq.). ${ }^{\mathrm{b}}$ Conversion determined by ${ }^{1} \mathrm{H}$ NMR. Isolated yield is given in brackets.

This latter technique enabled the reduction of the quantity of $\mathrm{KPF}_{6}$ and water used, and was found to be particularly efficient for salt $\mathbf{1 e}$ that reacts poorly in water due a reduced solubility. In the ball-mill, anion metathesis occurred in $30 \mathrm{~min}$ under solvent-free conditions. We first focused on the synthesis of complex 4c, featuring electron poor ClIPr ligand (Table 1). As discussed above, isolation of complexes featuring this ligand is difficult when the reaction is performed in solution. Reaction of $\mathbf{3 c}$ with silver(I) oxide in refluxing chloroform gave only $31 \%$ NMR conversion after $24 \mathrm{~h}$, and $90 \%$ after $48 \mathrm{~h}$ (Table 1 , entry 1). In dichloromethane at room temperature, with the addition of sodium hydroxide, it was possible to obtain full conversion of CIPr.HPF 6 3c in $24 \mathrm{~h}$ (Table 1, entry 2). However, upon isolation through filtration on Celite ${ }^{\circledR}$ and evaporation, complex 4c was obtained in only $45 \%$ yield. When imidazolium salt $3 \mathrm{c}$ was ballmilled with $\mathrm{NaOH}$ and $\mathrm{Ag}_{2} \mathrm{O}$ under solvent-free conditions at $30 \mathrm{~Hz}$ for $3 \mathrm{~h}, 100 \%$ conversion was also observed. More importantly, after the same treatment as when the reaction was performed in solution, homoleptic complex $\left[\mathrm{Ag}\left({ }^{\mathrm{Cl} I P r}\right)_{2}\right] \mathrm{PF}_{6} \mathbf{4 c}$ was isolated in $85 \%$ yield (Table 1, entry 3 ). The desired complex $\mathbf{4 c}$ may thus easily decompose in solution while the solvent-free approach gives a much faster access the complex and in a two-fold higher isolated yield. 

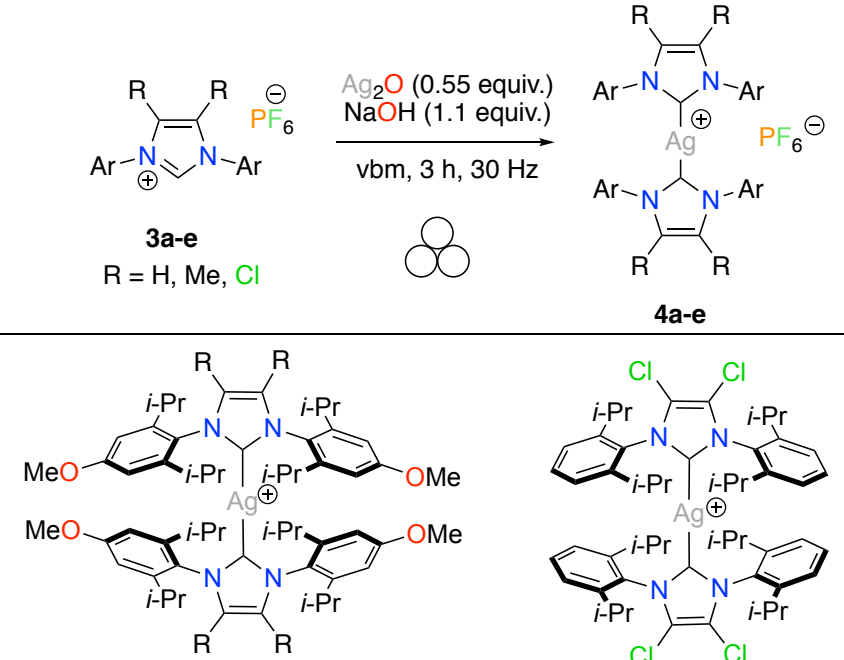

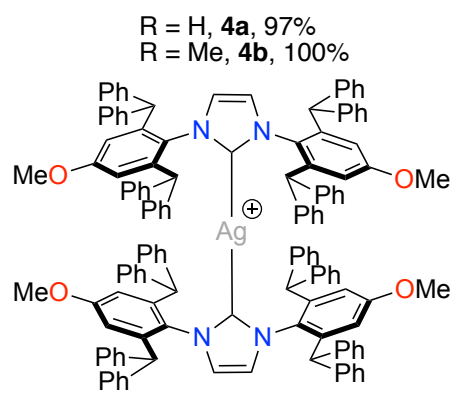

4d, $94 \%$

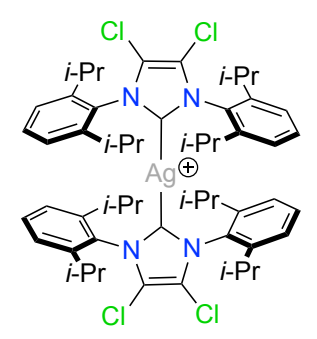

4c, $85 \%$

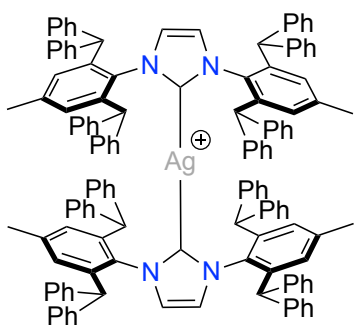

$4 e, 93 \%$
Scheme 2. Mechanosynthesis of homoleptic $\left[\mathrm{Ag}\left(\mathrm{NHC}_{2}\right] \mathrm{PF}_{6}\right.$ complexes bearing highly encumbered NHC ligands

The mechanochemical approach was then applied to salts 3a-e in the presence of silver oxide and sodium hydroxide (Scheme 2). As for complexes 2a-e, full conversion was observed in all cases in $3 \mathrm{~h}$ of milling. Homoleptic complexes $\mathbf{4 a}$ and $\mathbf{4 b}$ were isolated in excellent yields. The milling method was then applied successfully to poorly soluble IPr*0Me. $\mathrm{HPF}_{6} \mathbf{3 d}$. After $3 \mathrm{~h}$

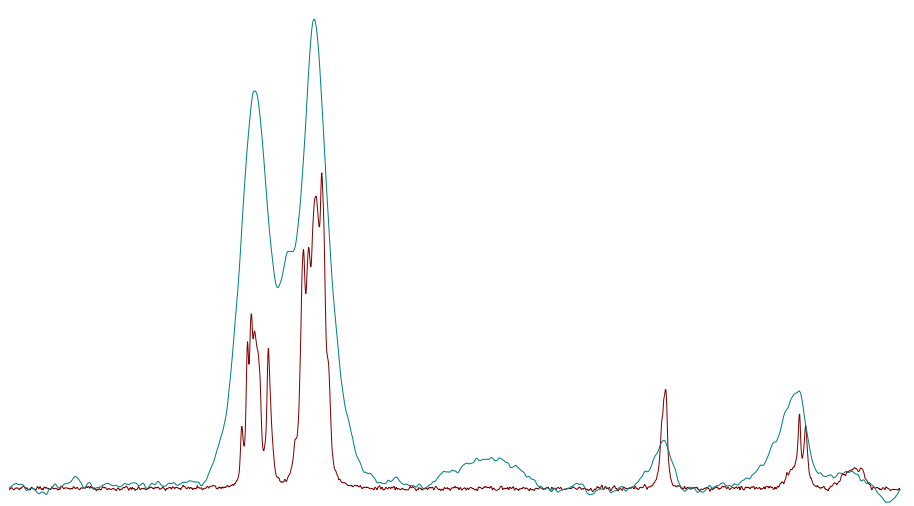

Figure $1 .{ }^{13} \mathrm{C}$ solid state HR-MAS NMR of IPr*.HPF 6 3e (red) and $\left[\mathrm{Ag}\left(\mathrm{IPr}^{*}\right)_{2}\right] \mathrm{PF}_{6}$ 4e (blue)

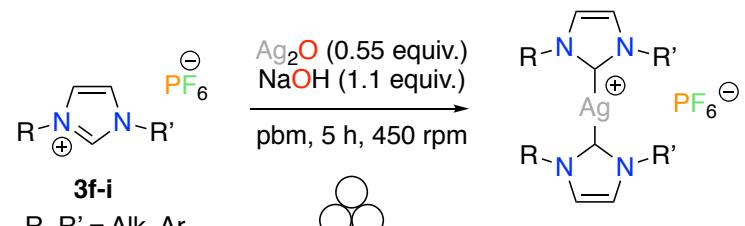

$\mathrm{R}, \mathrm{R}^{\prime}=$ Alk, Ar

4f-i
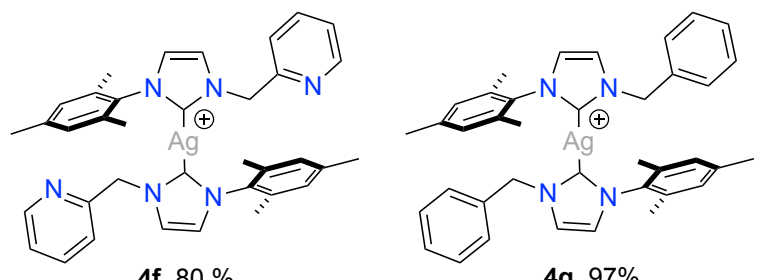

4f, $80 \%$
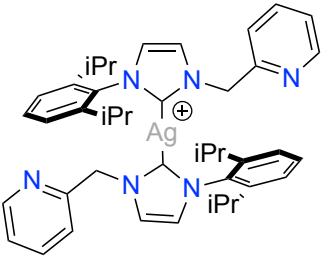

4h, $70 \%$

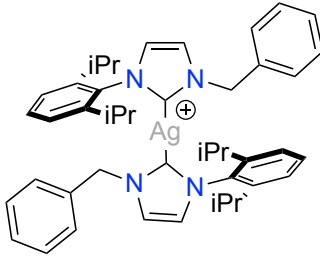

$4 i, 88 \%$

Scheme 3. Mechanosynthesis of homoleptic $\left[\mathrm{Ag}\left(\mathrm{NHC}_{2}\right] \mathrm{PF}_{6}\right.$ complexes bearing $N$-alkyl, $N$-aryl ligands

of milling at $30 \mathrm{~Hz}$, corresponding $\left[\mathrm{Ag}\left(\mathrm{IPr}^{* \mathrm{OMe}}\right)_{2}\right] \mathrm{PF}_{6} \mathbf{4 d}$ was isolated in $94 \%$ yield. On the other hand, $\left[\mathrm{Ag}\left(\mathrm{IPr}^{*}\right)_{2}\right] \mathrm{PF}_{6}$ 4e revealed highly unstable compared to $4 \mathbf{d}$, probably because of the worse $\sigma$-donation of IPr* compared to IPr*0Me. ${ }^{13,15}{ }^{1} \mathrm{H}$ NMR analysis showed the disappearance of the characteristic $\mathrm{C}-\mathrm{H}$ proton of the imidazolium salt $\mathbf{3 e}$, with the formation of corresponding complex 4e. Due to a quick decomposition of $\mathbf{4 e}$, it was impossible to obtain ${ }^{13} \mathrm{C}$ NMR analysis of the pure compound. ${ }^{16}$ Nevertheless, solid-state HR-MAS (high resolution magic angle spinning) ${ }^{13} \mathrm{C}$ NMR spectroscopy on a $600 \mathrm{MHz}$ spectrometer confirmed the formation of the complex with the appearance of the characteristic carbenic carbon signal of $4 \mathbf{e}$ at $182 \mathrm{ppm}$ (Figure 1). The low stability of $\left[\mathrm{Ag}\left(\mathrm{IPr}^{*}\right)_{2}\right] \mathrm{PF}_{6}$ 4e could explain the low yields when the reactions were performed in solution. Indeed, the best conversion obtained when the reaction was attempted in refluxing chloroform was $62 \%$ after $48 \mathrm{~h}$, yet along with important decomposition. ${ }^{16}$ Comparatively, complex $4 \mathbf{e}$ was isolated in $93 \%$ yield after $3 \mathrm{~h}$ of milling.

The synthesis of novel homoleptic complexes featuring $\mathrm{N}$-alkyl, $\mathrm{N}$-aryl ligands was next performed (Scheme 3 ). Reaction of imidazolium salt 3f, bearing a mesityl and a 2-picolyl group on the nitrogen atoms, was found to be slightly slower than with $\mathrm{N}, \mathrm{N}$-diaryl imidazolium 


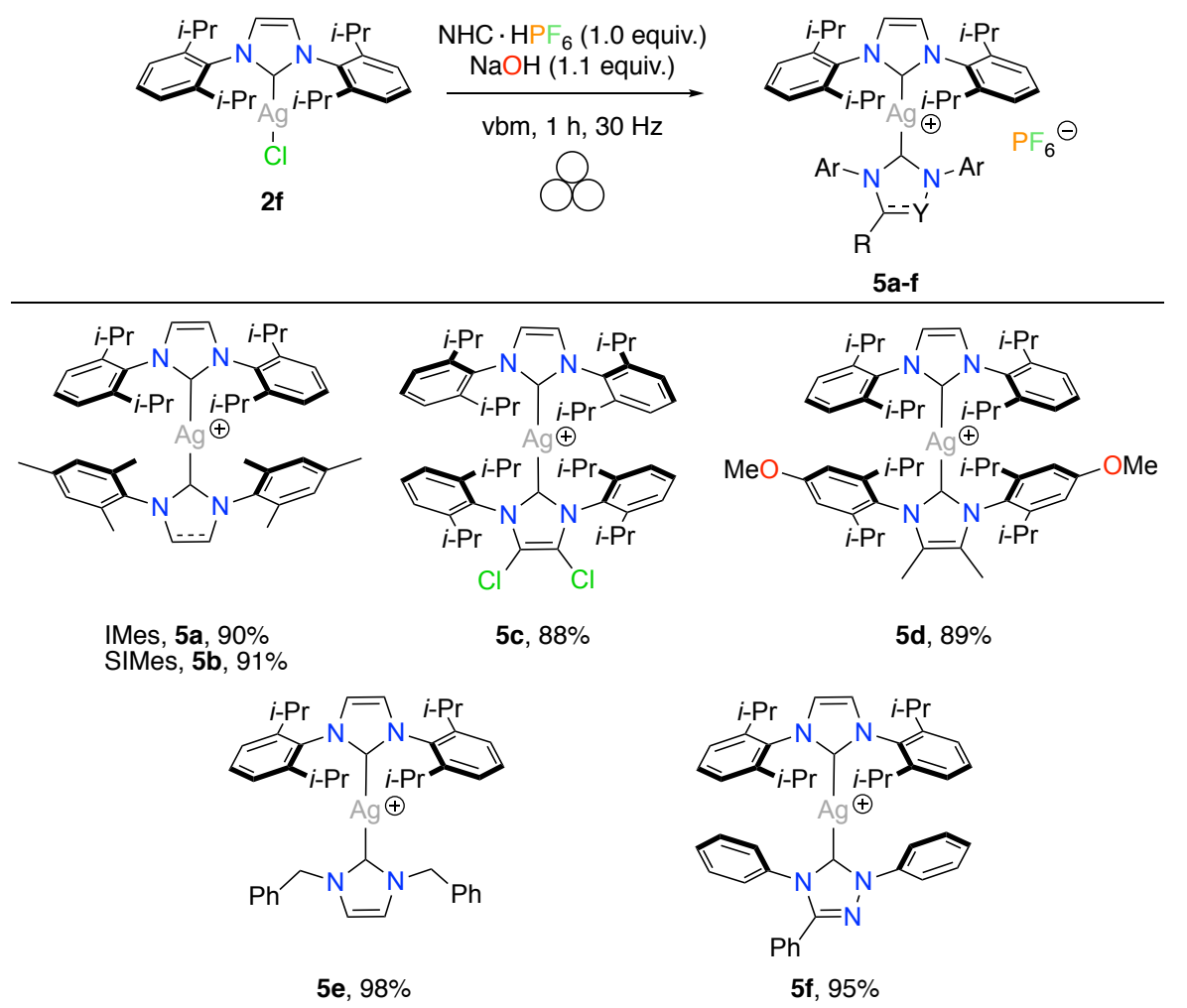

Scheme 4. Mechanosynthesis of cationic heteroleptic silver complexes

salts 3a-e, with $79 \%$ conversion after $3 \mathrm{~h}$ at $30 \mathrm{~Hz}$. Hence, reaction was performed using a planetary ballmill, which is more adapted to longer reaction times. After $5 \mathrm{~h}$ at $450 \mathrm{rpm}$, full conversion was obtained, yielding complex 4 ff in $80 \%$. With a similar ligand bearing a benzyl instead of the 2-picolyl group, reaction proceeded efficiently and $\mathbf{4 g}$ was isolated in $97 \%$ yield. Increasing the steric hindrance on the aromatic ring with a 2,6-diisopropylphenyl group resulted in slightly lower yields of $70 \%$ and $88 \%$ for $4 \mathrm{~h}$ and $4 \mathbf{i}$, respectively.

Finally, heteroleptic bis-NHC silver(I) complexes were synthesized using the vibratory ball-mill, starting from [AgCl(IPr)] 2f (IPr = 1,3-bis(2,6-diisopropylphenyl)imidazol-2-ylidene), which was prepared via mechanochemistry. ${ }^{9 a}$ To the best of our knowledge, the synthesis of heteroleptic silver(I) complexes was never attempted in a ball-mill. Reaction was thus first realized using classical IMes.HPF 6 (1,3-bis(2,4,6trimethylphenyl)imidazolium) and SIMes.HPF 6 (1,3bis(2,4,6-trimethylphenyl)imidazolinium) salts in the presence of sodium hydroxide (Scheme 4). After $1 \mathrm{~h}$ of milling at $30 \mathrm{~Hz}$ in a vibratory ball-mill, full conversions were obtained and heteroleptic complexes $\mathbf{5 a}$ and $\mathbf{5 b}$ were isolated in $90 \%$ and $91 \%$ yield, respectively. Reaction with ClIPr.HPF $_{6} \quad 3 \mathbf{c}$ and MeIPrOMe. $\mathrm{HPF}_{6} \mathbf{3 b}$ yielded corresponding complexes $\mathbf{5 c}$ and $\mathbf{5 d}$ in $88 \%$ and $89 \%$, respectively. To widen the scope of attainable heteroleptic complexes using this methodology, $\mathrm{N}, \mathrm{N}$-dibenzylimidazolium

a)
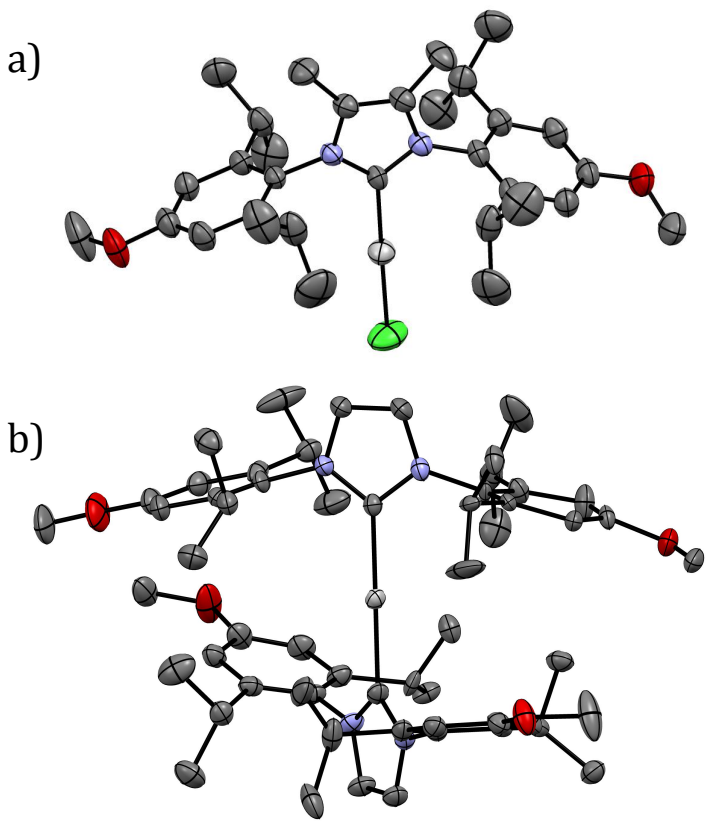

Figure 2. ORTEPs (at 50\% probability level) of compounds (a) 2b, (b) 4a. Hydrogen atoms and $\mathrm{PF}_{6}$ anion are omitted for clarity. 
Table 2. $\% V_{\text {bur }}$ for the different complexes

\begin{tabular}{ccccc}
\hline Entry & Complex & $\mathrm{d}_{\mathrm{C}-\mathrm{M}}(\AA)$ & \%Vbur $^{\mathrm{a}}$ & \%Vbur $^{\mathrm{b}}$ \\
\hline $\mathbf{1}$ & $\mathbf{2 a}$ & 2.080 & 40.2 & 41.3 \\
$\mathbf{2}$ & $\mathbf{2 b}$ & 2.087 & 42.8 & 42.5 \\
$\mathbf{3}$ & $\mathbf{2 e}$ & 2.078 & 52.9 & 52.9 \\
$\mathbf{4}$ & $\mathbf{4 a}$ & 2.099 & 38.7 & 38.7 \\
$\mathbf{5}$ & $\mathbf{4 b}$ & 2.122 & 40.2 & 40.7
\end{tabular}

a \%Vbur calculated with real C-Ag distance, sphere radius of $3.5 \AA$. b distance C-Ag normalized at $2.1 \AA$, sphere radius $3.5 \AA$.

hexafluorophosphate and TPT.HPF 6 (1,3,4-triphenyl1,2,4-triazolium hexafluorophosphate) were reacted efficiently to furnish $\mathbf{5 e}$ and $\mathbf{5 f}$ in excellent yields. X-ray quality crystals could be grown by slow diffusion of diethyl ether into a dichloromethane solution of complexes 2a, 2b, $\mathbf{4 a}$ and $\mathbf{4 b}$ (Figure 2). XRD analysis allowed to evaluate the steric properties of the ligands by calculating the $\% V_{\text {Bur }}$ (percent buried volume) of each complex using the SambVca web application (Table 2). ${ }^{17}$ As already witnessed with other metals, the introduction of methyl groups on the NHC backbone (2a vs $\mathbf{2 b}$ and $\mathbf{4 a}$ vs $\mathbf{4 b}$ ), which push the aromatic moieties towards the metal center, induces an increase in $\% V_{\text {Bur }}$ in each case. The increase of the sterical hindrance also results in a longer NHC-metal distance. In comparison, ligand IPr* was found to be extremely hindered as $\% V_{\text {Bur }}$ calculated for $2 \mathbf{e}$ reaches a value of 52.9 while the $\% V_{\text {Bur }}$ of the isopropyl analogues do not exceed the value of 42.8 .

Since homoleptic silver(I) complexes featuring benzimidazole $^{6 e}$ or imidazopyridine-based ${ }^{6 \mathrm{f}}$ NHC ligand have already shown promising activity against colorectal HCT116 cancer cell lines compared to 5fluorouracil or cisplatin, respectively, the unique capacity of mechanochemistry to generate rapidly a library of NHC silver complexes (2a-5f) prompted us to evaluate their cytotoxicity against this cell line. ${ }^{16}$ The percentage inhibition of cell proliferation was firstly measured using $10^{-5}$ and $10^{-6} \mathrm{M}$ solutions of the complexes (Figure 3). Half growth inhibition concentration $\left(\mathrm{IC}_{50}\right)$ was then measured only for compounds that showed high \% of inhibition at $10^{-6} \mathrm{M}$ (Figure 4). As a comparison, doxorubicin and cisplatin, which are commonly used to treat cancer, were evaluated on the same cancer cell line and possess $\mathrm{IC}_{50}$ of $810 \mathrm{nM}$ and $5.37 \mu \mathrm{M}$, respectively. In addition, [AgClIPr] 2f and $\left[\mathrm{Ag}(\mathrm{IPr})_{2}\right] \mathrm{PF}_{6} \mathbf{4 j}$ complexes were also tested to evaluate the influence of substitutions of the
Figure 3. Percentage of inhibition against HCT116 carcinoma cells at $10^{-5}$ and $10^{-6} \mathrm{M}$

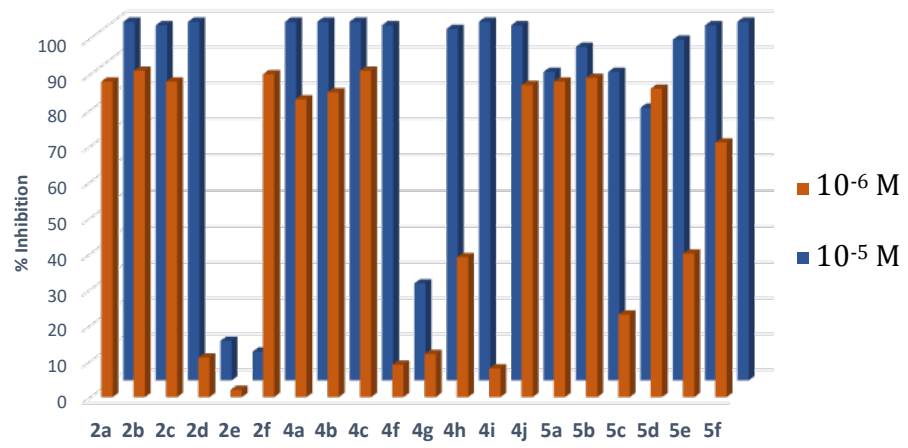

ligand on cytotoxicity. Among the neutral heteroleptic complexes 2a-f, only $\mathbf{2 d}$ and $\mathbf{2 e}$ were found almost inactive. Such behavior could be assigned to the poor solubility of the complexes in DMSO. Complex 2a showed an $\mathrm{IC}_{50}$ of $259 \mathrm{nM}$. As a comparison, 2f, which contains the classical IPr ligand, exhibited an $\mathrm{IC}_{50}$ of $390 \mathrm{nM}$, thus showing the positive influence of the methoxy groups on the NHC. The introduction of methyl group on the backbone of the NHC resulted in another positive effect as $\mathbf{2} \mathbf{b}$ was found to be active at $96.8 \mathrm{nM}$. On the other hand, 2c, featuring chlorine atoms on the backbone of the NHC, displayed an $\mathrm{IC}_{50}$ of $616 \mathrm{nM}$. Cationic homoleptic complexes having $\mathrm{N}, \mathrm{N}$ diaryl NHC ligands 4a-c displayed a higher cytotoxicity, with $\mathrm{IC}_{50}$ values down to $24.9 \mathrm{nM}$ for $\mathbf{4 b}$. Once again, the positive effect of the methoxy group

Figure 4. $\mathrm{IC}_{50}(\mathrm{nM})$ values against HCT116 carcinoma cells

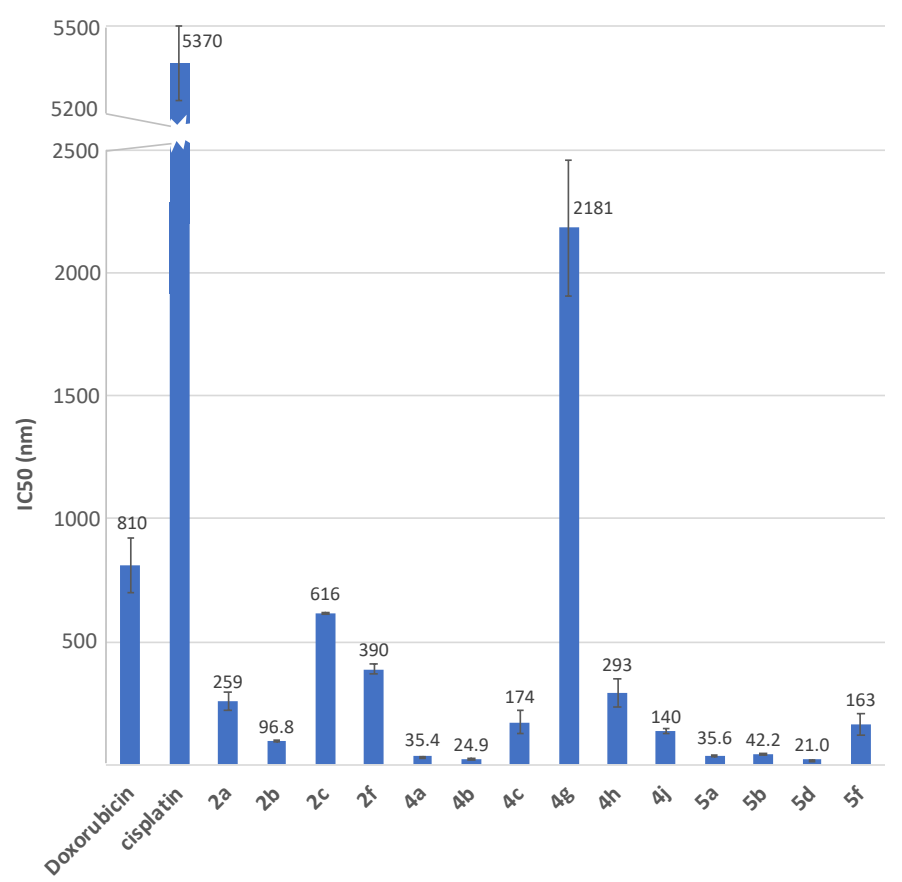


was demonstrated as $\left[\mathrm{Ag}(\mathrm{IPr})_{2}\right] \mathrm{PF}_{6}$ complex displayed on $\mathrm{IC}_{50}$ of $140 \mathrm{nM}$ (35.4 nM for $4 \mathbf{4 a}$ ). The addition of methyl goups on the NHC backbone results in even lower $\mathrm{IC}_{50}$ value (35.4 $\mathrm{nM}$ for $\mathbf{4 a}$ vs $24.9 \mathrm{nM}$ for $\mathbf{4 b}$ ). Homoleptic complexes 4f-i, containing $N$-aryl, $N$-alkyl NHC ligands, were found to be less active. In this family, $4 \mathrm{~h}$ was the most active, with an $\mathrm{IC}_{50}$ at $293 \mathrm{nM}$. Cationic bis-NHC silver complexes 5a-f also showed promising activity. 5a, featuring an IMes ligand, was more cytotoxic than $\mathbf{5 b}$ that contains the analogous saturated ligand. While very similar in structure, 5d, having one IPr ligand in place of MeIProMe, was found to be slightly more active than homoleptic $\mathbf{4 b}$, with the best $\mathrm{IC}_{50}$ of $21 \mathrm{nM}$. 4b is thus 256 and 38 times more active than cisplatin and doxorubicin, respectively. Interestingly, 5f, containing a TPT ligand, showed an IC $_{50}$ of $163 \mathrm{nM}$, thus demonstrating a possible diversification of the structure of the active complexes. On the other hand, 5c and 5e, featuring a ClIPr and a $\mathrm{N}, \mathrm{N}$-dibenzyl $\mathrm{NHC}$ ligand, respectively, were not as active, with a \% inhibition of cell proliferation below the values obtained for the other complexes. Thus, this preliminary study shows that introducing chlorine atoms on the backbone of the NHC, or using $\mathrm{N}$-alkyl, $\mathrm{N}$ aryl NHC ligands is detrimental to the biological activity. On the other hand, the MeIProme ligand, either in neutral heteroleptic or cationic complexes, seems to present the best positive effect on the cytotoxicity of the silver complexes. Of note, apart from $\mathbf{4 g}$, all the silver complexes tested displayed a higher cytotoxicity than doxorubicin and cisplatin.

In conclusion, Mechanochemistry overcame solutionbased chemistry, permitting to access rapidly and efficiently novel families of neutral heteroleptic and cationic homo- and heteroleptic complexes featuring NHC ligands bearing sterically hindering groups, and also electron-donating or -withdrawing substituents. Importantly, the use of ball-mills enabled the isolation of complexes difficult if not impossible to prepare and isolate using solution-based strategy. As preliminary results, the silver complexes showed high cytotoxic activity against colorectal HCT116 cancer cell line, with $\mathrm{IC}_{50}$ down to $21 \mathrm{nM}$, which is 256 times better than cisplatin.

\section{Acknowledgements}

The Université de Montpellier, Centre Nationale de la Recherche Scientifique (CNRS) and Agence Nationale de la Recherche (grant no. ANR-16-CE07-0009-01) are acknowledged for funding.

\section{References}

(1) (a) Díez-González, S.; Marion, N.; Nolan, S. P. Chem. Rev. 2009, 109, 3612-3676. (b) Lin, J. C. Y.; Huang, R. T. W.; Lee, C. S.; Bhattacharyya, A.; Hwang, W. S.; Lin, I. J. B. Chem. Rev. 2009, 109, 3561-3598.

(2) (a) Oehninger, L.; Rubbiani, R.; Ott, I. Dalton Trans. 2013, 42, 3269-3284. (b) Liu, W.; Gust, R. Chem. Soc. Rev. 2013, 42, 755-773. (c) Gautier, A.; Cisnetti, F. Metallomics 2012, 4, 23-32. (d) Mercs, L.; Albrecht, M. Chem. Soc. Rev. 2010, 39, 1903-1912. (e) Teyssot, M.L.; Jarrousse, A.-S.; Manin, M.; Chevry, A.; Roche, S.; Norre, F.; Beaudoin, C.; Morel, L.; Boyer, D.; Mahiou, R.; Gautier, A. Dalton Trans. 2009, 6894-6902. (f) Liu, W.; Gust, R. Coord. Chem. Rev. 2016, 329, 191-213. (g) Hu, C.; Li, X.; Wang, W.; Zhang, R.; Deng, L. Curr. Med. Chem. 2014, 21, 1220-1230.

(3) (a) Zou, T.; Lum, C. T.; Lok, C.-N.; Zhang, J.-J.; Che, C.M. Chem. Soc. Rev. 2015, 44, 8786-8801. (b) Bertrand, B.; Casini, A. Dalton Trans. 2014, 43, 4209-4219. (c) Cisnetti, F.; Gautier, A. Angew. Chem. Int. Ed. 2013, 52, 11976-11978. (d) Rieb, J.; Dominelli, B.; Mayer, D.; Jandl, C.; Drechsel, J.; Heydenreuter, W.; Sieber, S. A.; Kuehn, F. E. Dalton Trans. 2017, 46, 2722-2735. (e) Mora, M.; Gimeno, M. C.; Visbal, R. Chem. Soc. Rev. 2019, 48, 447-462. (f) Porchia, M.; Pellei, M.; Marinelli, M.; Tisato, F.; Del Bello, F.; Santini, C. Eur. J. Med. Chem. 2018, 146, 709-746.

(4) (a) Aher, S. B.; Muskawar, P. N.; Thenmozhi, K.; Bhagat, P. R. Eur. J. Med. Chem. 2014, 81, 408-419. (b) Hussaini, S. Y.; Haque, R. A.; Razali, M. R. J. Organomet. Chem. 2019, 882, 96-111. (c) Johnson, N. A.; Southerland, M. R.; Youngs, W. J. Molecules 2017, 22, 1263/1-1263/20. (d) Mohamed, H. A.; Willans, C. E. Organomet. Chem. 2014, 39, 26-50.

(5) (a) Mottais, A.; Berchel, M.; Le Gall, T.; Sibiril, Y.; d'Arbonneau, F.; Laurent, V.; Jaffres, P.-A.; Montier, T. Int. J. Pharm. 2019, 567, 118500. (b) Boubakri, L.; Dridi, K.; Al-Ayed, A. S.; Ozdemir, I.; Yasar, S.; Hamdi, N. J. Coord. Chem. 2019, 72, 2080-2090.

(6) (a) Sahin-Bolukbasi, S.; Sahin, N. J. Organomet. Chem. 2019, 891, 78-84. (b) Marinelli, M.; Santini, C.; Pellei, M. Curr. Top. Med. Chem. 2016, 16, 2995-3017. (c) Budagumpi, S.; Haque, R. A.; Endud, S.; Rehman, G. U.; Salman, A. W. Eur. J. Inorg. Chem. 2013, 4367-4388. (d) Eloy, L.; Jarrousse, A.-S.; Teyssot, M.-L.; Gautier, A.; Morel, L.; Jolivalt, C.; Cresteil, T.; Roland, S. 
ChemMedChem 2012, 7, 805-814. (e) Haque, R. A.; Choo, S. Y.; Budagumpi, S.; Iqbal, M. A.; Al-Ashraf Abdullah, A. Eur. J. Med. Chem. 2015, 90, 82-92. (f) Jhulki, L.; Dutta, P.; Santra, M. K.; Cardoso, M. H.; Oshiro, K. G. N.; Franco, O. L.; Bertolasi, V.; Isab, A. A.; Bielawski, C. W.; Dinda, J. New J. Chem. 2018, 42, 13948-13956. (g) Iqbal, M. A.; Haque, R. A.; Budagumpi, S.; Khadeer Ahamed, M. B.; Abdul Majid, A. M. S. Inorg. Chem. Commun. 2013, 28, 64-69. (h) Iqbal, M. A.; Haque, R. A.; Ahamed, M. B. K.; Majid, A. M. S. A.; Al-Rawi, S. S. Med. Chem. Res. 2013, 22, 2455-2466. (i) Asif, M.; Iqbal, M. A.; Hussein, M. A.; Oon, C. E.; Haque, R. A.; Khadeer Ahamed, M. B.; Abdul Majid, A. S.; Abdul Majid, A. M. S. Eur. J. Med. Chem. 2016, 108, 177-187.

(7) (a) Beillard, A.; Bantreil, X.; Métro, T.-X.; Martinez, J.; Lamaty, F. Chem. Rev. 2019, 119, 7529-7609. (b) Howard, J.; Cao, Q.; Browne, D. L. Chem. Sci. 2018, 9, 3080-3094. (c) Andersen, J.; Mack, J. Green Chem. 2018, 20, 1435-1443. (d) Hernández, J. G.; Bolm, C. J. Org. Chem. 2017, 82, 4007-4019. (e) Do, J.-L.; Friščić, T. ACS Central Science 2017, 3, 13-19. (f) Rightmire, N. R.; Hanusa, T. P. Dalton Trans. 2016, 45, 2352-2362. (g) Hernández, J. G.; Friščić, T. Tetrahedron Lett. 2015, 56, 4253-4265. (h) Wang, G.-W. Chem. Soc. Rev. 2013, 42, 7668-7700. (i) Takacs, L. Chem. Soc. Rev. 2013, 42, 7649-7659. (j) James, S. L.; Adams, C. J.; Bolm, C.; Braga, D.; Collier, P.; Friščić, T.; Grepioni, F.; Harris, K. D. M.; Hyett, G.; Jones, W.; Krebs, A.; Mack, J.; Maini, L.; Orpen, A. G.; Parkin, I. P.; Shearouse, W. C.; Steed, J. W.; Waddell, D. C. Chem. Soc. Rev. 2012, 41, 413-447.

(8) Beillard, A.; Bantreil, X.; Métro, T.-X.; Martinez, J.; Lamaty, F. Dalton Trans. 2016, 45, 17859-17866.

(9) (a) Beillard, A.; Bantreil, X.; Métro, T.-X.; Martinez, J.; Lamaty, F. New J. Chem. 2017, 41, 1057-1063. (b) Beillard, A.; Golliard, E.; Gillet, V.; Bantreil, X.; Métro, T.X.; Martinez, J.; Lamaty, F. Chem. Eur. J. 2015, 21, 17614-17617.

(10) (a) Chakraborty, B. J. Heterocycl. Chem. 2019. (b) Oliveira, P. F. M.; Guidetti, B.; Chamayou, A.; AndréBarrès, C.; Madacki, J.; Korduláková, J.; Mori, G.; Orena, B. S.; Chiarelli, L. R.; Pasca, M. R.; Lherbet, C.; Carayon, C.; Massou, S.; Baron, M.; Baltas, M. Molecules 2017, 22, 1457. (c) Tirapegui, C.; Acevedo-Fuentes, W.; Dahech, P.; Torrent, C.; Barrias, P.; Rojas-Poblete, M.; Mascayano, C. Bioorg. Med. Chem. Lett. 2017, 27, 16491653. (d) Tan, D.; Loots, L.; Friscic, T. Chem. Commun. 2016, 52, 7760-7781.

(11) Gaillard, S.; Slawin, A. M. Z.; Bonura, A. T.; Stevens, E. D.; Nolan, S. P. Organometallics 2010, 29, 394-402.

(12) Elie, M.; Sguerra, F.; Di Meo, F.; Weber, M. D.; Marion, R.; Grimault, A.; Lohier, J.-F.; Stallivieri, A.; Brosseau, A.; Pansu, R. B.; Renaud, J.-L.; Linares, M.; Hamel, M.; Costa, R. D.; Gaillard, S. ACS Appl. Mater. Interfaces 2016, 8, 14678-14691.
(13) Meiries, S.; Speck, K.; Cordes, D. B.; Slawin, A. M. Z.; Nolan, S. P. Organometallics 2013, 32, 330-339.

(14) Berthon-Gelloz, G.; Siegler, M. A.; Spek, A. L.; Tinant, B.; Reek, J. N. H.; Marko, I. E. Dalton Trans. 2010, 39, 1444-1446.

(15) (a) Nelson, D. J.; Collado, A.; Manzini, S.; Meiries, S.; Slawin, A. M. Z.; Cordes, D. B.; Nolan, S. P. Organometallics 2014, 33, 2048-2058. (b) Huynh, H. V. Chem. Rev. 2018, 118, 9457-9492.

(16) See Supporting Information for details.

(17) (a) Poater, A.; Cosenza, B.; Correa, A.; Giudice, S.; Ragone, F.; Scarano, V.; Cavallo, L. Eur. J. Inorg. Chem. 2009, 1759-1766. (b) Clavier, H.; Correa, A.; Cavallo, L.; Escudero-Adán, E. C.; Benet-Buchholz, J.; Slawin, A. M. Z.; Nolan, S. P. Eur. J. Inorg. Chem. 2009, 2009, 17671773. (c) Clavier, H.; Nolan, S. P. Chem. Commun. 2010, $46,841-861$. 